Research article

\title{
Three cases of feet and hand amputation from Medieval Estremoz, Portugal
}

\author{
Teresa Fernandes $^{\mathrm{a}, \mathrm{b}, *}$, Marco Liberato ${ }^{\mathrm{c}}$, Carina Marques ${ }^{\mathrm{b}, \mathrm{d}}$, Eugénia Cunha ${ }^{\mathrm{d}}$ \\ a Department of Biology, University of Évora, 7002-554 Évora, Portugal \\ ${ }^{b}$ Research Center for Anthropology and Health (CIAS), Department of Life Sciences, University of Coimbra, Coimbra, Portugal \\ ${ }^{c}$ Foundation for the Science and Technology (PhD Fellowship)/Research Center in Archaeology, Arts and Heritage Sciences, Portugal \\ d Laboratory of Forensic Anthropology, Department of Life Sciences/Center of Functional Ecology, University of Coimbra, Coimbra, Portugal
}

\section{A R T I C L E I N F O}

\section{Keywords:}

Limb amputation

Severing

Punishment

Trauma

Perimortem

\begin{abstract}
A B S T R A C T
Peri-mortem limb amputations are rarely reported in the paleopathological literature. The cases reported here concern severing of both hands and feet observed in three adult male skeletons, exhumed from the medieval Portuguese necropolis of Rossio do Marquês de Pombal, Estremoz, Portugal. The fact that they were found in the same site, in graves placed side by side, that all are young males, and that the three skeletons show similar perimortem injuries, make this a unique case meriting detailed analysis. Considering the lesions' location and pattern, as well as historical data, we hypothesize that this is a case of amputation as a consequence of judicial punishment. Estremoz was an important city in sustaining the Royal power at a regional scale during the medieval period.
\end{abstract}

\section{Introduction}

Evidence of amputation, revealed through the analysis of archaeological human skeletal remains, is relatively uncommon. Still, the paleopathological literature provides sporadic evidences of such practice, from diverse chronological, sociocultural, and geographic contexts (Mays, 1996; Stuckert and Kricun, 2011). The great majority of paleopathological cases of limb amputations previously reported, are diagnosed through the evidence of healing of the stump, whereas cases of perimortem amputations are considerably scarcer. The latter are likely underreported, due to the troublesome distinction between perimortem and postmortem trauma in dry bones, which still represents a great challenge to paleopathology (Mays, 1996; Buckberry, 2014; De Boer et al., 2015).

Three male individuals exhumed from the medieval necropolis of Rossio Marquês de Pombal (13th-15th centuries), Estremoz, Portugal, show lesions compatible with perimortem amputations observed in the forearms and lower limb bones. Preliminary observation in situ revealed the presence of severed hands and feet with stumps, placed under or near the body, yet the bones of these extremities were all in anatomical articulation.

The aim of the present paper is to provide a holistic approach to the interpretation of such finding, by establishing interconnections between the biological, sociocultural, and historical dimensions of these human practices (Ingold, 2005). A holistic framework is drawn by analyzing the skeletal remains in conjunction with cultural and historical framing of punitive acts. Therapeutic actions, judicial punishment, ritual practices, accidental injury or interpersonal violence might all be hypothesized as underlying causes of limb amputations in past human societies (Mays 1996; Buckberry, 2014). As such, it is our goal to describe the lesions observed and to discuss the possible causes of the amputations documented in these three medieval individuals.

\section{Materials and methods}

The necropolis of Rossio Marquês de Pombal (RMPE) is located in Estremoz, a city in southern Portugal, close to the Spanish border. Estremoz was an important geostrategic medieval village, as witnessed by the construction of its famous medieval Castle and the associated Royal Court. The RMPE necropolis was uncovered in 2001 during the construction of a parking lot. A total of 126 graves were identified, 84 (66.6\%) of which were excavated, as well as eight ossuaries. A total of 97 skeletons were retrieved, with 67 (69.1\%) corresponding to adult skeletons. Radiocarbon dating of two skeletons established a chronological boundary between the 13th and 15th centuries (BP 680-530 and BP $670-530$, for 2 Sigma calibration, 95\% probability, Beta Analytic Laboratories). Three of the adult skeletons exhumed (RMPE 116, RMPE 117 and RMPE 118) are the focus of the present work.

Most of the graves were dug in the stone or directly in the ground, having an anthropomorphic shape and well delimited. It is noteworthy that the graves of the three individuals under study were located side by side in the south corner of the cemetery, which corresponds to the limits

\footnotetext{
* Corresponding author at: Department of Biology, University of Évora, 7002-554 Évora, Portugal.

E-mail address: tmf@uevora.pt (T. Fernandes).
} 


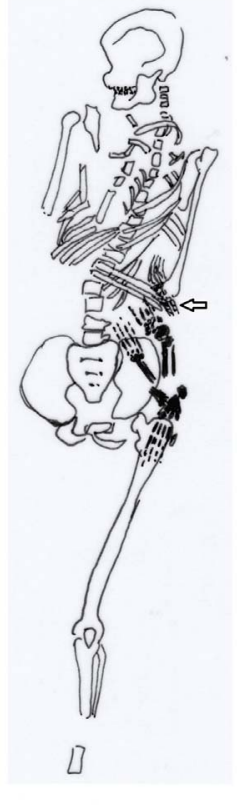

RMPE 116
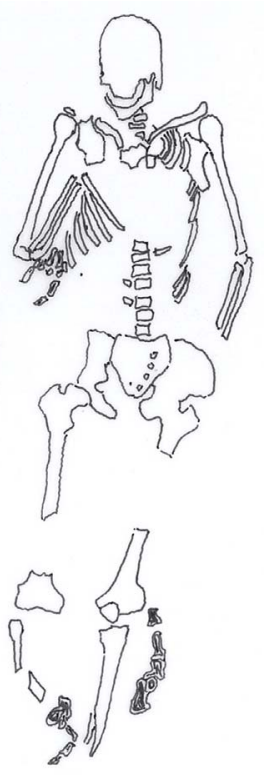

RMPE 117

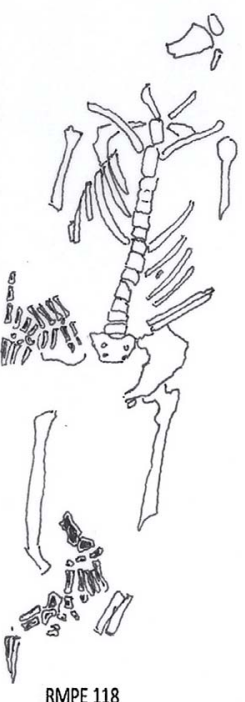

RMPE 118

Fig. 1. Field draw (scale 1:10) of the skeletons RMPE 116,117, and 118. The arrow points the right hand lying below the left elbow.

of the necropolis, in an area with lesser burial density. Moreover, these graves were poorly delimited and without anthropomorphic shape. No other features of the mortuary practices were atypical for these three cases. The three bodies were laid in decubitus dorsalis, with head towards West and feet to East. Observation in situ revealed that the hands and feet were separated from the forearms and forelegs, and located under or on the side of the skeletons, yet the hands and feet had all bones in anatomical articulation (Fig. 1), indicating a primary deposition. During fieldwork, it was also possible to observe cut marks on forearms and lower leg bones. Some post-depositional disturbances, due to a previous intervention to place electric cables, were detected in grave RMPE 116 causing disarticulation of the right lower limb, which was kept inside the grave.

Age at death estimation was obtained following the recommendations of Işcan et al. (1984), Mincer et al. (1993), Scheuer and Black (2000), and Coqueugniot and Weaver (2007). The protocol for morphological sex estimation followed standard osteological techniques recommended by Buikstra and Ubelaker (1994). Stature was evaluated using the regression equations of Santos (2002) applicable on the metatarsal bones. Macroscopic identification of perimortem trauma followed the standard guidelines of forensic anthropology literature (Symes et al., 2002; Kimmerlee and Baraybar, 2008; Symes et al., 2012; Berryman et al., 2013; Quatrehomme, 2015); in addition to the recommendations of the Scientific Working Group for Forensic Anthropology (2011).

\section{Results}

\subsection{Case I: RMPE 116}

Cranial bones were mostly destroyed postmortem, however the mandible was well preserved. The postcranial skeleton had most of its bones present, as can be seen in Fig. 1, with an overall high degree of preservation.

Skeleton RMPE 116 exhibited morphological features compatible with a male individual based on cranial and pelvic morphology, and it is the youngest of the three individuals. Third molar root apices were still open (Mincer et al., 1993), the distal epiphyses of the ulna and radius were not completely fused, and the distal epiphyseal line of the

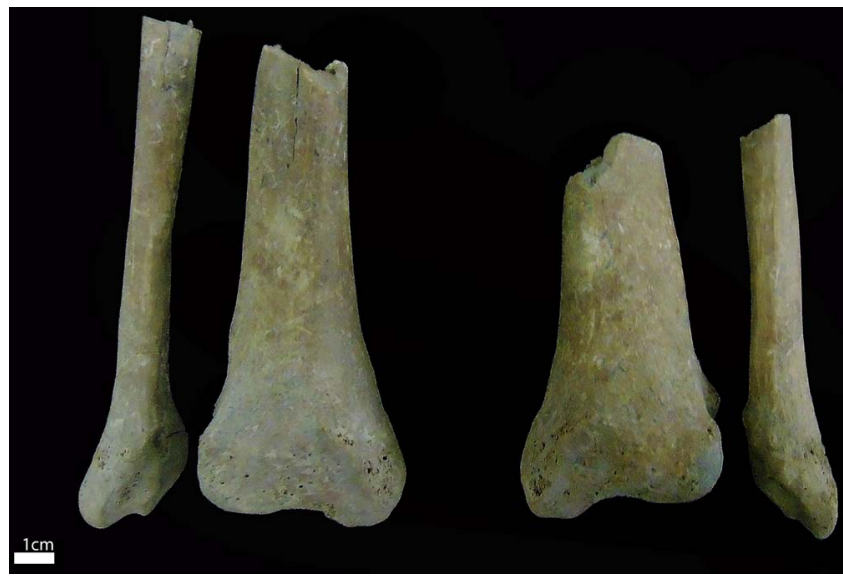

Fig. 2. Oblique cuts in the distal third of the diaphysis of the fibulae and tibiae noticed in the skeleton RMPE 116.

fibulae was also visible. Ossification stage of the sternal end of the clavicle suggests an age below 25 years old (Scheuer and Black, 2000; Coqueugniot and Weaver, 2007). Considering all of the age at death indicators, it can be inferred that the age bracket of this individual was probably between the ages of 18-20 years old at the time of death. Regression equations (Santos, 2002) for stature indicated a height of approximately $170 \pm 5.4 \mathrm{~cm}$.

Both forearms show an oblique and complete fracture of the distal third of the diaphyses, leading to the complete separation of the hands and a small portion of stump (stump length is approximately five centimeters for the radii and seven centimeters for the ulnae). Cut marks are oblique and located slightly higher in the ulnae in relation to the radii. Both fibulae and tibiae show cut marks affecting the distal third of the diaphyses (Fig. 2). The lesion's outline is regular and with the same color as the surrounding cortical bone, and the cuts are oblique with sharp edges. Macroscopically, it is also possible to observe striations parallel to the kerf floor (Fig. 3). The feet and the stumps of the forelegs (stump length is $10 \mathrm{~cm}$ for the tibiae and $11 \mathrm{~cm}$ for the fibulae) were completely separated. Interestingly, the feet and left hand were placed under the left femur and pelvis, while the right hand was placed under the left elbow, as it can be seen in Fig. 1. Hands and feet were complete with all bones in anatomical articulation, suggesting that the severing of the extremities was intentional and happening while the joint soft tissue was still preserved, precluding postdepositional disturbances, decay, or other taphonomic agents.

\subsection{Case II: RMPE 117}

Skeleton RMPE 117 had most of the bones present (Fig. 1), however

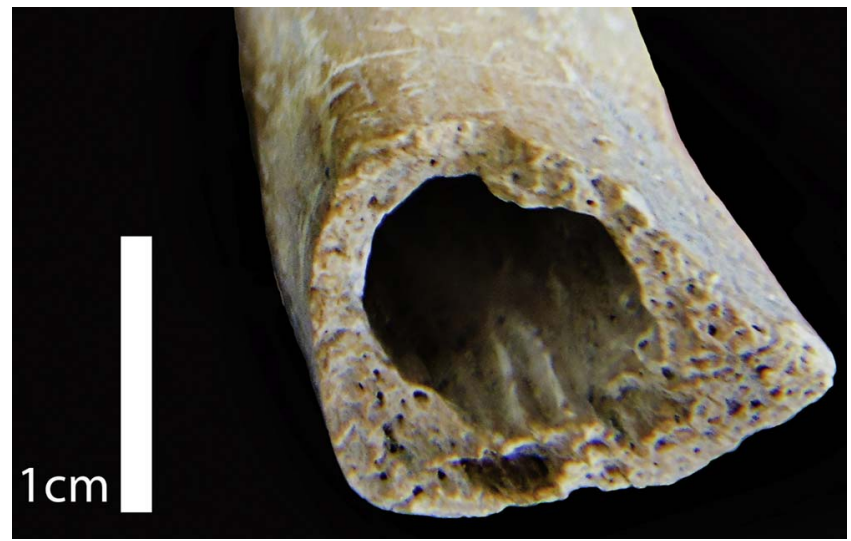

Fig. 3. Striations parallel to the kerf floor in the right distal extremity of the fibula, observed in the skeleton RMPE 116. 


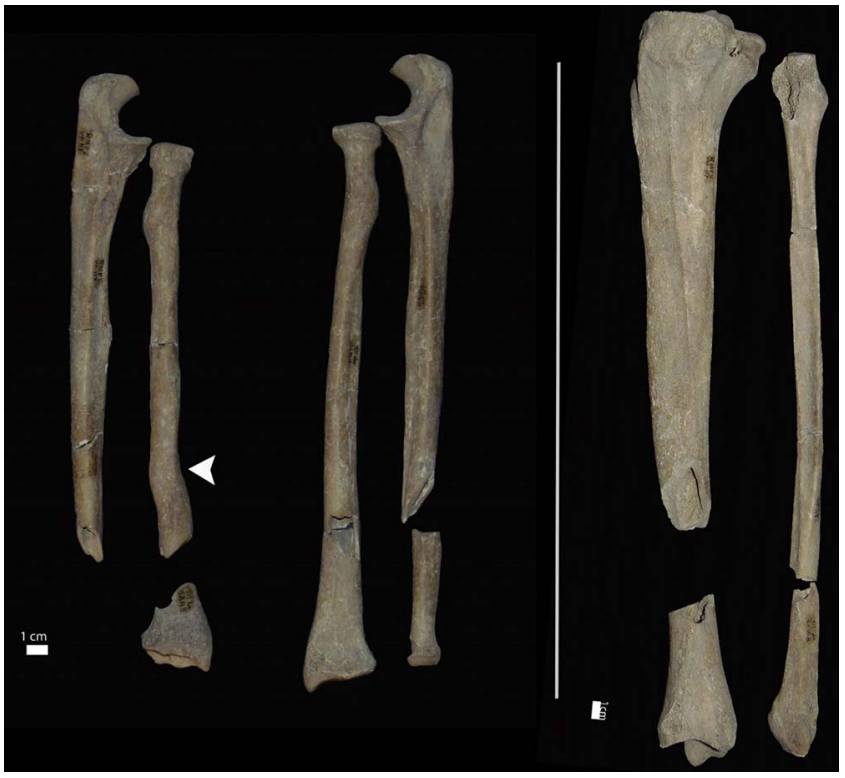

Fig. 4. Skeleton RMPE 117 shows bilateral evidence of a cut affecting the upper limb (distal portion) and distal portion of the left tibia and fibula. It is also evident a callus of a remodeled fracture in the diaphysis of the left radius (arrow head).

they were fragmented or incomplete at the time of laboratory data collection.

Regarding the biological profile, skull and pelvic bones display a male morphology. Age at death indicators, such as sternal end of the 4th rib, non-fusion of the first sacral vertebra (S1-S2), fusion of the iliac crest, closed apices of 3rd molar roots (Mincer et al., 1993), point to an age at death between 25 and 35 years old. This young male had a stature of approximately $171 \pm 5.4 \mathrm{~cm}$.

Although unrelated with the aim of the present work, we must point out that two antemortem lesions are noticeable: a callus of an old fracture visible in the diaphysis of the left radius, with diaphyseal misalignment and distortion (Fig. 4), and a possible slipped femoral capital epiphysis (identified based on the guidelines described in Ortner (2003) in the left coxo-femoral region.

Cut marks are visible bilaterally in the forearms and forelegs of this skeleton (Fig. 4). The forearms have transverse cuts affecting the radii and ulnae on their distal third (Fig. 4). Closer examination of the cut surface shows regular striations and margins with the same coloration as the surrounding bone. The right ulna shows a more regular cutting surface than the ipsilateral radius. Based on the way the striations are oriented and stepped, the direction of the lesion progressed from superior to inferior and lateral to medial planes. The left tibia was also severed in its distal third, leading to the separation of the bone in two main portions with a few associated fragments. Margin outline is regular and sharp, with a "V" shaped cross section, with striations seen macroscopically. The left fibula was also severed at the same level and with the similar features of the tibia. Analysis of the right leg cut marks is not straightforward, due to the poor state of preservation. In the right fibula there are cuts at the same level as the contralateral one but the affected area has postmortem damage precluding a clear evaluation. Moreover, from the right tibia only fragments were recovered after the excavation.

Once again, the severed hands and feet with the stumps (measuring approximately eight centimeters for the radii, seven centimetrs for the ulnae, $10 \mathrm{~cm}$ for the tibiae and nine centimeters for the fibulae) were placed around the body (Fig. 1). The right foot was placed between the legs, whereas the left one was on the left side of the fibula. Hands were located under the right elbow. In terms of relative depth, feet were in an upper level and hands were in a lower one. Bones of the extremities were in anatomic articulation and complete, not showing evidence of cut marks.

\subsection{Case III: RMPE 118}

Skeleton RMPE 118 was incomplete (Fig. 1). There was a plant root inside the grave that had a major effect on postmortem destruction. Hands and feet were the only bones that were well preserved. We hypothesize that the location of the extremities under the body (right foot between the legs, left one under the right femur, and hands were placed near the right pelvis) might have contributed to differential preservation. A micro taphonomic environment may have been created around the extremities, protecting the hand and foot bones from adverse effects of the root penetrating the rest of the skeleton. Thus, bone fragmentation precluded an accurate analysis of the cuts noticed in this skeleton, as well as a narrow age at death estimation. Thus, this male skeleton assessment based on the morphology of the pelvis - was considered an adult, owing to the complete epiphyseal fusion observed in all bones. No further age at death indicators were evaluated. The stature is approximately $173 \pm 5.4 \mathrm{~cm}$.

Notwithstanding the degree of fragmentation, perimortem trauma was still noticeable in both upper and lower limbs, namely a severed distal end of the right ulna and radius, as well as the distal ends of tibiae and fibulae. The stumps associated with the hands and feet measured approximately six sentimeters for the radii, five centimetrs for the ulnae, $11 \mathrm{~cm}$ for the tibiae and $10 \mathrm{~cm}$ for the fibulae. Both the right tibia and fibula diaphyses display one false start (identified through the presence of a kerf), indicating that the cuts were performed after at least one failed attempt (Fig. 5). These false starts are located posteriorly in the bone surface, which indicates a posterior to anterior direction of the cuts. Again, all bones were sectioned at the same level. Notably, the very regular margin observed in the lower extremity of the right tibia is suggestive of a blow delivered with high energy.

\section{Discussion}

\subsection{Perimortem or postmortem amputation?}

Except for the lesions in the forearms and leg bones, no other evidence of perimortem trauma was found in the skeletons surveyed. Cut marks on the distal extremities of the forearms and lower leg bones, with severing of hands and feet, suggests an amputation of the extremities likely happening around the time of death. The lesion's features suggest that these are compatible with the action of a sharp

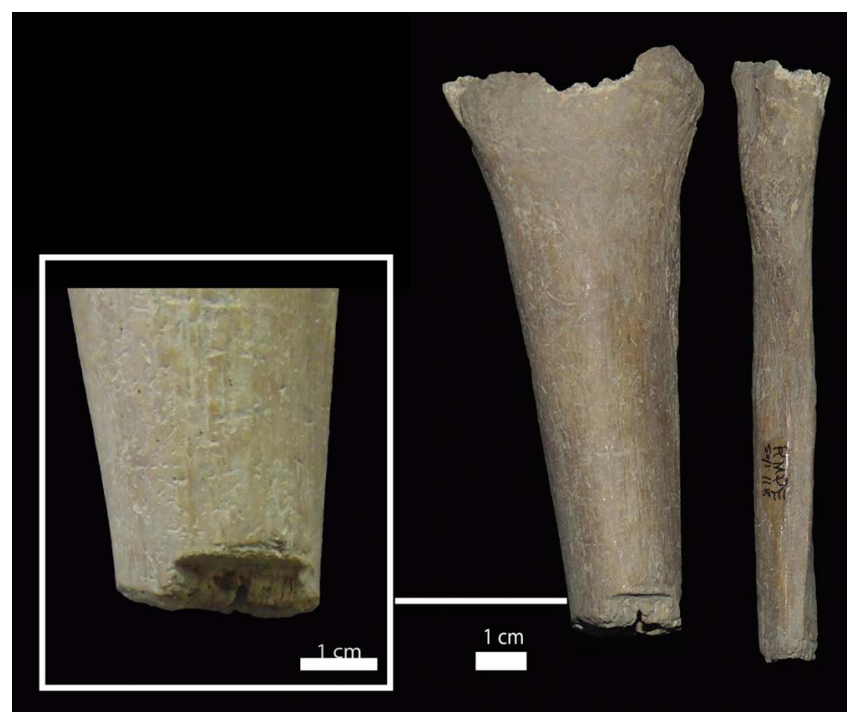

Fig. 5. Right fibula and tibia showing evidences of cut observed in skeleton RMPE 118. A false start is noticed in the tibia. 
instrument, such as a machete, sword, cleaver, hatchet or axe, with the blow delivered swiftly and with high force.

It should be noted that skeleton RMPE 117 shows a perimortem comminuted fracture (indicated by the presence of bone fragments) on both the left tibia and fibula, suggesting that the two bones were cut with the same type of instrument (e.g. axe). It could also suggest a single and very strong blow. Larger and heavier sharp objects may generate enough force when swung to amputate a limb. The symmetry of the cut marks suggests that the legs were straight and parallel to each other when the cuts were done. Furthermore, the forearm cut marks on this skeleton are oblique and were probably done from above (upward to downward) using an instrument like an axe or a sword.

Due to the features of the lesions observed in the three skeletons, a perimortem etiology seems highly likely. Based on the similar color of the fracture edges and the surrounding bone, as well as the sharpness of the edges, most probably the fractures were done when the bone was still fresh. This indicates that the damage happened perimortem and not after the bone was exposed to significant decomposition. While it is well known that perimortem bone trauma can only be directly related to the cause of death when located near vital organs, it is also feasible to hypothesize that in the absence of effective means of hemorrhage control or medical assistance, amputations like the ones herein described, could have led to the death of these individuals. In amputations visibility of the cut surfaces can be preserved up to 13 days after the procedure, while "capping" of the medullary cavity starts after few weeks (De Boer et al., 2015). Thus, it is reasonable to hypothesize that these individuals did not survive, at least not for long, following the amputations since no macroscopic osteogenic response was noticed.

One other hypothesis worth exploring is the possibility that these amputations occurred postmortem, as a consequence of corpse dismemberment shortly after death while the soft tissues still preserved the anatomical integrity of the hands and feet. Historical accounts reveal that the practice of postmortem evisceration, excarnation, or dismembering were relatively common in medieval Europe. These practices, were often used in order to transport the body of the deceased to the homeland when death took place in foreign lands, being most commonly used for members of the clergy and nobleman (Weiss-Krejci, 2008). This hypothesis is not likely for the cases under study, since the only anatomic areas separated from the body were the hands and feet.

Postmortem dismembering following execution, as a form of punishment inflicted upon the corpse, also prevailed in this chronological period in Europe (Westerhof, 2013; Ward, 2015). Decapitation and quartering of the already lifeless body of individuals executed publicly aimed not only to set an example, but also as a form of public shaming and dishonoring, as the integrity of the corpse was valuable under medieval Christian morality (Ward, 2015). These actions had a symbolic meaning signifying not only a biological death but also a social one (Ward, 2015), with the intent to "disable and denigrate the corpse" Knüsel and Martin, 2013: 683). Lewis (2008) describes skeletal evidence of such procedure in one individual from medieval England, showing multiple perimortem lesions associated with quartering, as a form punishment, that occurred after death. Yet, the multiplicity of lesions in the same individual, characteristic of quartering, is absent in the skeletons herein described.

Postmortem decapitation- with placement of the skull in the gravehave also been encountered in paleopathological publications (e.g. Romano-British cemeteries (Tucker, 2013)), and attributed to a wide variety of reasons (e.g. ritual performances, to allow or prevent the souls to enter afterlife, or to prevent the dead from returning to haunt the living (Tucker, 2013)). However, we found no historical or paleopathological accounts of such postmortem symbolic procedures applied exclusively to the amputation of the hands and feet. Furthermore, Ward (2015) notes that prior to the 16th century it was more customary to inflict punishment on live bodies, with a shift towards postmortem penalties after this period. For these reasons we consider that a postmortem dismemberment is less likely for the cases herein described.
As far as we know, this is the very first time a case involving three individuals with both arms and lower legs severed perimortem have been found in the same medieval necropolis. Paleopathological cases of perimortem limb amputations were also not previously reported in a Portuguese necropolis. Some examples are depicted in the paleopathological literature for other geographic regions. For example, in England, Redfern (2007) and Stuckert and Kricun (2011) mention a male skeleton with perimortem transmetarsal amputation of both feet, exhumed from the Roman-British cemetery of Lankhills. Because of the similarity with the present cases, we would also refer the possible perimortem limb amputation involving the distal right radius, ulna and hand in a post-medieval sub-adult from the Isle of Wight (Redfern, 2007). For the Roman period in Britain, an amputation is known from Dorchester (Booth et al., 2010). A male from the Anglo-Saxon cemetery of Blacknall Field, Wiltshire, also shows a possible perimortem amputation of the lower legs (Stuckert et al., 2010). In all, perimortem amputations are not often found in archaeological contexts, however evidence of this practice with healing features are more frequent (Mays, 1996).

\subsection{Inferring the reasons for the perimortem amputation}

Several interpretations can be posited as reasons for the perimortem amputation of the limb extremities in three young adult males buried side by side. These include therapeutic, judicial punishment, ritual, or as result of accidental injury or interpersonal violence (Mays 1996; Kirkup, 2007; Buckberry, 2014). However, for the present cases the reasons underlying the mutilation of the four extremities could be reduced to two: interpersonal violence and punishment. In the present cases, it seems easy to exclude an assault with a weapon such as a sword or axe, since it would have been very improbable that the four extremities of the same individual could have been severed in a consistent, systematic way in the context of a violent assault.

Undoubtedly, medieval weapons were capable of severing a limb (Mays, 1996). Knife, hammer, heavy mallet, sword, blade, are examples of such weapons (Mays, 1996). In agreement with Mitchell (2004: 114) we also argue that "amputation of part of a limb is suggestive of punishment when evidence from this [practice] is found in legal records for the period of the burial, especially if the cut is at right angles to the bone and more than one limb is amputated in a symmetrical manner" (Mitchell, 2004: 114). Although the cuts in our cases are oblique, they do have a bilateral presentation and were identified in more than one limb. As such, punishment is likely the cause of the lesions described in this report. For the present paper punishment is understood as "penalties imposed by those in power against those who were found responsible for transgressing the limits of what was deemed acceptable behaviour and practice" (Marafioti and Gates, 2014: 9), but it also includes extra-judicial violence related to sociopolitical contexts, such as warfare, political, or religious motivations. Capital punishment or corporal mutilations, often inflicted publicly on the individual, functioned as instruments of social control (Marafioti and Gates, 2014), a staging of political power, and of "surveillance in a Foucaudian sense" (Westerhof, 2013:178). Punitive procedures inflicted upon the body by excision of limbs and body parts have a long history and wide range of cultural contexts (Kirkup, 2007). Capital punishment, punitive amputation, and torture of war captives are also well documented for the medieval period in Europe (Mitchell 2004; 2006; Kirkup, 2007). Thus, political and religious motives could also be evoked. For this period, criminals convicted of theft or murder could also be subjected to torture (Mitchell, 2006). Geltner (2014) notes that in the fourteenth and fifteenth centuries, branding, amputations, and flogging occurred. Moreover, the author states that thieves and counterfeiters were subject to sentences involving amputated hands. (Peters (1998: 37) states that in the "Christian kingdoms of the Iberian Peninsula at the end of the 12th century, it was still in the king's right to inflict capital punishment (hanging, drowning, boiling alive) as well as mutilation (punitive 
amputation of hands and feet, noses, lips, ears and breasts in the case of women, blinding, fines and imprisonment)". Historical records are in clear concordance with some of these practices being used in Portugal as well. Regarding the late medieval period in Portugal, from the analysis of a voluminous set of documents from the 15th century - among which we can highlight nearly five thousand letters of royal forgiveness to criminals - Duarte (1999) concludes that the death penalty or severe body mutilations before were relatively rare, and only applied to individuals considered very dangerous. Nevertheless, it is possible to say that the cutting of hands, subsequently exposed to the public in the streets, was practiced until 1500, when king D. Manuel ordained that the amputated parts should be buried immediately, after the application of the punishment (Gonçalves, 1996). It is possible that the cutting of all limbs would represent a punishment only applied to very serious crimes. The early medieval chronicles studied by Lopes (1970) and current works on this subject by Duarte (1999), show that the amputation of hands and feet, while the individual was alive, was a punishment applied to some of the supporters of prince $D$. Afonso who opposed king $D$. Dinis during the civil war in the beginnings of the 14th century (Lopes, 1970). These are well-documented examples of punishment associated with political motives experienced in medieval Portugal.

Occurrence in Estremoz of a similar penalty could be related to its major role in the Royal administrative system. From 1258 onwards, when D. Afonso III granted a royal charter to Estremoz, a series of royal initiatives proceeded with the aim of transforming the small town into a military stronghold (Liberato, 2012). In less than two decades, Estremoz became one of the most important urban centres of southern Portugal. The monarchs themselves stayed frequently in town, in part to personally oversee the application of judicial penalties, one of the most important royal functions during the Middle Ages (Gomes, 1995), as such it becomes likely that judicial punishments would occur in this city. To illustrate this argument, we recall that in 1478, king Alfonso $V$ informed the Duke of Bragança of the burning of a man as punishment, an action that took place in Estremoz (AHCB). This was the only case known up to now of this kind of punishment in the 15th century in Portugal (Duarte, 1999). Two major inferences can be drawn from this event. The king brought a criminal to Estremoz to be penalized through an unusual and very dramatic method, and temporarily revoked the House of Bragançás privilege to apply justice in their domains (Cunha, 1990). This was likely as a warning addressing potential defiance of the Royal power in the region. Based on the above-mentioned arguments, it is probable that a severe punishment by amputation had occurred in medieval Estremoz.

Finally, it is worth commenting on the mortuary behaviour as support for the above-mentioned hypothesis of punishment. Although the individuals were not thrown in a shared or shallow grave or buried in an atypical position or orientation, the mortuary treatment shows some differences when compared with the remaining burials. The three individuals under study were buried in graves located side by side and relegated to a peripheral border space of the necropolis. The graves were slightly different in typology from the other interments, as they had no anthropomorphic shape nor were delimited by stone walls, possibly revealing a less elaborate or careful burial procedure. It can be conjectured that this burial practice symbolizes a deliberate intention of exclusion or segregation of the wrong-doers. Marafioti and Gates (2014: 7) note that in the Anglo-Saxon period some instances were recorded where "executed bodies were confined to shallow, short, or shared graves [...], relegated to their own cemeteries, typically located in border areas which sometimes doubled as execution site". Furthermore, due to the side by side deposition, a similar lesion pattern and similar biological profile, we could also hypothesize that the three individuals might have been involved with the same crime.

\section{Conclusions}

In all, blows from sharp weapons as a punitive procedure is the most probable cause of the perimortem injuries here reported. There is no other case of amputations reported in the Portuguese archaeological record involving three individuals from the same necropolis. This is the first time a Portuguese medieval case of such severe punishment is reported from a paleopathological perspective, thus enlarging the dataset for this type of procedure in medieval Europe. Historical records show that the city of Estremoz was an important locus of the Royal administrative system. These skeletons may represent the testimony of vigorous application of justice as an act of royal sovereignty in a peripheral but militarily strategic region. Furthermore, amputation of body parts as the result of punishment was historically documented for the medieval period in Portugal. These cases also illustrate how bodies are axiomatically viewed as "the first and foremost natural instrument to give meaning to and conceptually structure their environment and social interactions" (Westerhof, 2013: 177).

\section{Acknowledgements}

Research Center for Anthropology and Health (CIAS), Fundação para a Ciência e a Tecnologia, Department of Biology, University of Évora, Departamento de Ciências da Vida, University of Coimbra. We would like to express our enormous gratitude to Tom Gundling for the helpful comments and review of the manuscript. We are thankful for the Editor and anonymous reviewers that with their suggestions and comments improved this manuscript.

\section{References}

AHCB - Arquivo Histórico da Casa de Bragança, NNG 702r fl. $104 \mathrm{v}$

Berryman, H., Shirley, N., Lanfear, A., 2013. Low-velocity trauma. In: Tersigni-Tarrant, M.T., Shirley, N. (Eds.), Forensic Anthropology: An Introduction. CRC Press, Boca Raton, FL, pp. 291-306.

Booth, P., Simmonds, A., Boyle, A., Clough, S., Coll, H.E.M., Poore, D., 2010. The Late Roman Cemetery at Lankhills, Winchester, Excavations 2000-2005, Oxford Archaeology Monograph 10. Oxford Archaeology, Oxford.

Buckberry, J., 2014. Osteological evidence of corporal and capital punishment in late Anglo-Saxon England. In: Gates, J.P., Marafioti, N. (Eds.), Capital and Corporal Punishment in Anglo-Saxon England. The Boydell Press, Suffolk, pp. 131-148.

Buikstra, J.E., Ubelaker, D.H., 1994. Standards for data collection from human skeletal remains. In: Proceedings of a Seminar at the Field Museum of Natural History. Arkansas Archaeological Survey Research Series, 44.

Coqueugniot, H., Weaver, T., 2007. Brief communication: Infracranial maturation in the skeletal collection from Coimbra, Portugal: New aging standards for epiphyseal union. Am. J. Phys. Athropol. 134, 424-437.

Cunha, M.S. da, 1990. Linhagem, Parentesco E Poder. A Casa De Bragança. Fundação da Casa de Bragança, Viseu, pp. 1381-1483.

De Boer, H.H., van der Merwe, A.E., Hammer, S., Steyn, M., Maat, G.J.R., 2015. Assessing posttraumatic time interval in human dry bone. Int. J. Osteoarchaeology. 25, 98-109.

Duarte, L.M., 1999. Justiça E Criminalidade No Portugal Medievo. Fundação Calouste Gulbenkian, Lisbon, pp. 1459-1481.

Geltner, G., 2014. History of corporal punishment. In: Bruinsma, G., Weisbird, D. (Eds.), Encyclopedia of Criminology and Criminal Justice. Springer, New York, pp. 2106-2115.

Gomes, R.C., 1995. A Corte Dos Reis No Final Da Idade Média. Lisbon. Difel, Lisbon.

Gonçalves, I., 1996. Pela ribeira de lisboa, em finais da idade Média. In: Gonçalves, I. (Ed.), Um Olhar Sobre a Cidade Medieval. Patrimonia Historica, Cascais, pp. 61-76. Ingold, T., 2005. Companion Encyclopedia of Anthropology. Routledge, London.

Işcan, M., Loth, S., Wright, R., 1984. Age estimation from rib by phase analysis: white males. J. Forensic Sci. 29, 1094-1104.

Kimmerlee, E.H., Baraybar, J.P., 2008. Sharp force trauma. In: Kimmerlee, E.H., Baraybar, J.P. (Eds.), Skeletal Trauma: Identification of Injuries Resulting from Human Rights Abuse and Armed Conflict. CRC Press, Boca Raton, FL, pp. 263-299.

Kirkup, J., 2007. A History of Limb Amputation. Springer-Verlag, London.

Knüsel, C., Martin, S., 2013. The Routledge Handbook of the Bioarchaeology of Human Conflict. Routledge, London.

Lewis, M.A., 2008. A traitor's death? The identity of a drawn, hanged and quartered man from Hulton Abbey, Staffordshire. Antiquity 82, 113-124.

Liberato, M., 2012. Núcleos urbanos e afirmação de soberania no Alentejo duocentista: o caso de Estremoz. In: García Fitz, F., Jiménez Alcázar, J. (Eds.), La Historia Peninsular En Los Espacios De Frontera: Las Extremaduras Históricas Y La Transierra (Siglos XI-XV). Sociedade Espanhola de Estudios Medievales, Madrid, pp. 189-204.

Lopes, F.F., 1970. Santa Isabel na contenda entre D. Dinis e o Filho (1321-1322) 8. Lusitania Sacrapp. 57-80. 
Marafioti, N., Gates, J.P., 2014. Capital and Corporal Punishment in Anglo-Saxon England. The Boydell Press, Suffolk.

Mays, S., 1996. Healed limb amputations in human osteoarchaeology and their causes: a case study from Ipswich, UK. Int. J. Osteoarcbaeol. 6, 101-113.

Mincer, H.H., Harris, E.F., Berryman, H.E., 1993. The A.B.F.O. study of third molar development and its use as an estimator of chronological age. J. Forensic Sci. 38, 290-390.

Mitchell, P.D., 2004. Medicine in the Crusades: Warfare, Wounds and the Medieval Surgeon. Cambridge University Press, Cambridge.

Mitchell, P.D., 2006. The torture of military captives during the crusades to the medieval Middle East. In: Christie, N., Yazigi, M. (Eds.), Noble Ideals and Bloody Realities: Warfare in the Middle Ages, 378-1492. E. J. Brill, Leiden, pp. 97-118.

Ortner, D., 2003. Identification of Pathological Conditions in Human Skeletal Remains, 2nd. Academic Press, San Diego.

Peters, E.M., 1998. Prisons before prison: the ancient and medieval worlds. In: Morris, N., Rothman, D. (Eds.), The Oxford History of the Prison: the Practice of Punishment in Western Society. Oxford University Press, New York, pp. 3-43.

Quatrehomme, G., 2015. Traité d'anthropologie medico-légale. De boeck, Louvain.

Redfern, R.C., 2007. An investigation on of possible peri-morten limb amputation in a post-medieval subadult from the Isle of Wight, Engand. Paleopathol. Newsl. 140, 6-11.

Santos, C.M., 2002. Estimativa da Estatura a Partir dos Metatársicos. Master Thesis. Coimbra University, Coimbra.

Scheuer, L., Black, S., 2000. Developmental Juvenile Osteology. Academic Press, London.

Scientific Working Group for Forensic Anthropology, 2011. Trauma Analysis. In: http:// swganth.startlogic.com/Trauma\%20Rev0. pdf. Last acessed 01/10/2016.

Stuckert, C.M., Kricun, M.E., 2011. A case of bilateral forefoot amputation from the
Romano-British cemetery of Lankhills, Winchester, UK. Int. J. Paleopathol. 1 , 111-116.

Stuckert, C., Annable, F.K., Eagles, B.N., 2010. Chapter IV: the human remains. In: Annable, F.K., Eagles, B.N., The Anglo-Saxon Cemetery at Blacknall Field, Pewsey, Wiltshire. Wiltshire Archaeological and Natural History Society Monograph, 4, Devizes, 111-137.

Symes, S., Williams, J., Murray, E., Hoffman, J.M., Holland, T., Saul, J.M., Saul, F., Pope, E., 2002. Taphonomic context of sharp-force trauma in suspected cases of human mutilation and dismemberment. In: Haglund, W., Sorg, M. (Eds.), Advances in Forensic Taphonomy. Method, Theory and Archaeological Perspectives. CRC Press, Boca Raton, FL, pp. 403-434.

Symes, S., L'Abbé, E., Chapman, E., Wolf, I., Dirkmaat, D., 2012. Interpreting traumatic injury to bone medicolegal investigations. In: Dirkmaat, D. (Ed.), A Companion to Forensic Anthropology. Blackwell Publishing, 340-389.

Tucker, K., 2013. The osteology of decapitation burials from Roman Britain: a postmortem burial rite? In: Knüsel, C., Martin, S. (Eds.), The Routledge Handbook of the Bioarchaeology of Human Conflict. Routledge, London, pp. 213-236.

Ward, R., 2015. A Global History of Execution and the Criminal Corpse. Palgrave Macmillan, Hampshire.

Weiss-Krejci, E., 2008. Unusual life, unusual death and the fate of corpse: a case study from dynastic Europe. In: Murphy, E. (Ed.), Deviant Burial in the Archaeological Record. Oxbow Books, Oxford, pp. 169-190.

Westerhof, D.M., 2013. Amputating the traitor: healing the social body in public executions for treason in late medieval england. In: Akbari, S., Ross, J. (Eds.), The Ends of the Body: Identity and Community in Medieval Culture. University of Toronto Press, Toronto, pp. 177-192. 